\title{
Tax Compliance of Muslim Entrepreneurs in the City of Makassar
}

\author{
Andi Kusumawati ${ }^{1}$, Mustakim Muchlis ${ }^{2}$ \\ \{andiuma88@gmail.com¹, mustakim.muchlis@uin-alauddin.ac.id ${ }^{2}$ \} \\ Faculty of Economics and Business, Hasanuddin University, Makassar, Indonesia. ${ }^{1}$ \\ Universitas Islam Negeri Alauddin, Makassar, Indonesia ${ }^{2}$
}

\begin{abstract}
The purpose of this study is to reveal Muslim entrepreneurs' people's perceptions of tax compliance related with knowledge, religiosity and justice and to find out whether knowledge, religiosity and justice affect them or not in terms of their tax compliance. The informants of this research are Muslim entrepreneurs in Makassar City. Data was collected through interviews with informants and analysed with a phenomenological approach. A result showed that tax compliance of Muslim entrepreneur is on what is detected into their tax payable. A Religiosity specs affect their views regarding taxes which they consider to be something that should not need to be imposed on citizens but they remain compliant with detected taxes. Knowledge helps in reporting tax and helps them to identify gray areas. While in the aspect of justice, all informants thought that there had not been justice in terms of taxation and what they got from what they paid.
\end{abstract}

Keywords:

Tax Compliance, Muslim Entrepreneurs, Religiosity, Knowledge, Justice

Article Received: 18 October 2020, Revised: 3 November 2020, Accepted: 24 December 2020

\section{Introduction}

[1] Indonesia income that comes from taxes amounted to $81 \%$ of the total state revenue. Revenue from the source is relatively still small when seen from the potential that is there when maximized. Realization of tax revenue can be achieved when taxpayer compliance has been running optimally. [2] But based on existing data the level of tax compliance in Indonesia is still below. The indications can be seen from several things, namely the number of registered taxpayers, the return on tax returns, tax ratio and tax gap.

[3] Taxpayer compliance is the main factor in determining the amount of tax revenue that can be collected by the Directorate General of Taxes. Tax compliance behaviour is one of several phenomena that have affected the global economy, and this has become a material for practitioners and academics to conduct in-depth studies. [4] Tax compliance behaviour is considered as an important phenomenon that affects developed and developing economies. While the phenomenon that occurs that the level of tax non-compliance in developing countries is far more than developed countries.

The tax collection system that applies in Indonesia is a Self-Assessment system where taxpayers are given the trust to calculate, pay, and report their own taxes. This system encourages taxpayers to be more transparent and responsible in calculating their own taxes, which is certainly good. Even so, taxpayers might try to manipulate their finances to reduce their need to pay taxes or even make them zero. This of course makes taxpayers does not become compliant.

The Directorate General of Tax (DJP) recorded on 2018 compliance ratio of annual tax $71 \%$. The ratio was down compared to 2017. Compliance ratio is calculated from the ratio between the number of tax returns received against the number of taxpayers are obliged to submit SPT. In 2018, for the 2017 tax return many tax returns, taxpayers did not report the return tax return as did the previous year. The Ministry of Finance is targeting 2018 reporting for 2018 compliance can increase $85 \%$.. This is based 
on the ease of SPT reporting provided by the Directorate General of Taxes to the public through online payment via e-billing and electronic reporting via e-filing.

[5] Realization of tax revenue from Small and Medium Enterprises (SMEs) is still too low. Efforts made by reducing the SMEs final income tax rate $(\mathrm{PPh})$ from $1 \%$ to $0.5 \%$ are expected to increase the level of tax compliance. The reduction of the final SMEc Final Income rate is stated in Government Regulation (PP) Number 23 of 2018 concerning Income Tax on Income from Entrepreneurs Received or Obtained by Taxpayers who have a Specific Gross Distribution. The regulation is a substitute for PP No. 46 of 2013. Besides being expected to increase compliance, the policy scheme is expected to be able to contribute to the economy in the medium term. Expected to increase the entrepreneur's spirit to further develop

This Condition, Raising question, is all the tax breaks and conveniences able to raise taxpayer compliance? Research related to factors that influence tax compliance behaviour has been done a lot; of course tax compliance factors are very diverse. These factors can come from internal taxpayers themselves or from external or the environment around taxpayers. Many studies conducted on tax compliance see this phenomenon from the start of [6] tax knowledge, [7] tax justice, [8] economic perspective, [9] behaviour, [10] Spiritual and emotional intelligences (Mahdi). Latest research related tax compliance emphasize the importance of the factors explored the impact of noneconomic related tax compliance from a number of perspectives like the internal values of individuals mainly from her like family values, culture, nationalism and religion.

$$
\text { Based on introduction }
$$
above, this study wants to examine taxpayer compliance in this case Muslim entrepreneurs who run the business in Makassar City. Muslim entrepreneurs who are used as informants in this study are entrepreneurs who are not only entrepreneurs people who are Muslim but in this study specialized researchers who run their entrepreneurs do not conduct transactions that are prohibited in religion such as the existence of usury, gharar and maysir in their transaction activities. This selective election was carried out as an effort to gain understanding from Muslim entrepreneurs who have tried to become perfect Muslims rather than secular. Using a qualitative approach, this study intends (1) to reveal Muslim entrepreneur's people's perceptions of tax compliance related to their knowledge, religiosity and fairness, and (2) to find out whether knowledge, religiosity and justice affect them or not in terms of compliance they are tax related.

\section{Method}

This research is using qualitative (nonmainstream). Non-mainstream approach is taken because research related to positive tax compliance paradigm has been carried out and several studies provide suggestions for conducting research using non-mainstream paradigms. The researcher conducted this research to reveal the perception of Muslim entrepreneurs about tax compliance associated with knowledge, religiosity and justice.

[11] Creswell says that the Qualitative research has the objective to understand research by way of studying social problems or human. This study uses an interpretive paradigm that focuses on the mind-set, ethics and human behaviour which is considered as an action that involves intentions, awareness, and certain reasons that depend on the meaning and interpretation of humans in understanding and viewing social phenomena.

This study was designed to obtain in-depth results about the compliance behaviour of research taxpayers not specifically to generalize to broader groups. Therefore, this research is a research that seeks to merge into a phenomenon that is analysed in a way that researchers try to find detailed explanations that may be hidden and difficult to obtain. [12] Edmonds \& Kennedy 
explains that the approach is used to uncover and understand certain phenomena without attempts to influence the phenomena that occur.

In order to obtain data, this study uses a semi-structured questionnaire as a guide in interview activities. All informants interviewed used the same set of questions. Semi-structured questionnaire offers a more flexible approach in the interview process. [12] Researchers have sufficient discretion in trying to obtain more detailed explanations, such as the instantaneous thinking of informants. Researchers use guide questions as a systematic attempt to talk so that when leaving the topic will return to the main topic of conversation again.

In determining informants, purposive and snowball sampling were applied. Purposive sampling is carried out to select informants who have been in business for several years and have known tax obligations on their business activities. As for the objects of research are Muslim entrepreneurs in the city of Makassar. Muslim entrepreneurs are not only entrepreneurs who have Islamic religions, but in this paper the researcher specializes in entrepreneurs who are certainly Muslim then their business is to sell goods / services that are not prohibited by religion, business processes are carried out according to the rules of sharia transactions that there are no Ribawi transactions, maysir and gharar. Selective selection is done in an effort to gain understanding from Muslim entrepreneurs who have tried to become Muslims who are not secular.

Table 1: List of Informants

\begin{tabular}{lll}
\hline No & Name & Entrepreneurs type \\
\hline $\mathbf{1}$ & Faizal & Drugstore \\
\hline $\mathbf{2}$ & Mahyudi & Culinary and Property \\
\hline $\mathbf{3}$ & Zulfikar & Property \\
\hline $\mathbf{4}$ & Fitri & Course Services \\
\hline
\end{tabular}

\section{Results and Discussion}

\section{Tax compliance}

[13] Tax compliance defines as accurate reporting of income and expense claims in accordance with applicable tax law. [13] Kirchler defines more simply, tax compliance as the most neutral term to describe the willingness of taxpayers to pay their tax owed.

Tax compliance applies to anyone in a country of law. One of them is a businessman. [13] Successful entrepreneurs are those who can build a good business culture. As business people who live in a country, it is fitting for them to comply with the rules in force in that country. Whatever their beliefs, they should also obey the rules of the country. In Indonesia, entrepreneurs have obligations in terms of taxation, both central and regional taxes. The central tax consists of $\mathrm{PPn}, \mathrm{PPnBm}, \mathrm{PPh}$ and PBB while regional taxes such as Billboard Tax, Hotel tax, Restaurants and others.

The informants interviewed in this study consisted of four informants. Each of them has a different type of entrepreneurs. So that the tax obligations imposed on them could be different. There are Muslim entrepreneurs who are only subject to income tax; some are also subject to VAT, regional tax and advertisement tax. Among them have views that can be the same and can also be different with regard to taxes, compliance with taxes, religiosity associated with taxes; their knowledge is associated with tax compliance and their views regarding tax justice.

The informants interviewed in this study consisted of four informants. Each of them has a different type of business. So that the tax obligations imposed on them could be different. There are Muslim entrepreneurs who are only subject to income tax; some are also subject to PPn, local tax and advertisement tax. Among them have views that can be the same and can also be different with regard to taxes, compliance with taxes, religiosity associated with taxes; their knowledge is associated with tax compliance and their views regarding tax justice.

The following are some of the results of interviews conducted with informants. The first research question is related to their compliance with taxes.

Mr Faizal (Pharmacy Entrepreneur) 
"Tax is a lot, PPh PPn, if we get taxable from the employee side, we get our bonus, our work is deducted. The tax is unfair, if we get our income from the entrepreneur, we get the income. This tax is mandatory, we must obey same ulil amri although the heart is not calm ... If business income is related to the government then I pay, because it appears that for other income well sorry I did not report".

From the statement of the interview results and the researchers' knowledge of the informant. Consciously and responsibly, the informant understands his responsibility as an inmate of citizens. According to him, tax is an obligation of citizens who have become taxpayers, although honestly he does not like to be taxed because he feels there is an injustice in the collection and deduction both he as an employee or an entrepreneur. He assumed that he had worked and when he could earn either automatically or on his own initiative he had to pay and report taxes and that was considered unfair. But even so he still complies with tax obligations imposed on income from his business or other activities. It's just that compliance with only the tax is detected, while the undetected he considers unnecessary because he already feels that the detected income is enough to give to the state.

Understanding tax as an obligation of citizens towards the state is also almost the same as the next informant. He is a Culinary and Property Entrepreneur. $\mathrm{He}$ is a Muslim businessman who is also still an employee in a large company in Makassar City. Next, the results of the interview with Mahyudi:

"The tax is related to the system adopted by a country ... So far in Indonesia tax is considered as one of the state revenues, to run the wheels of the country's economy ... In contrast to Muslim countries there is no tax ... If in Indonesia the country has the right to take, entitled to collect taxes ... The tax depends on the individual .. If we as citizens of Indonesia must follow the rules as citizens, like it or not must want ... the legal basis for taxes is mandatory, so we must pay ... If I am a taxpayer the income should be deducted, please cut it, especially now that the government is more transparent in tax reporting, so this helps taxpayers".

In understanding from the second informant, he has understood very well that the Indonesian state needs the care of its citizens to help finance the country's development through the obedience of citizens who voluntarily pay and report their taxes to the state. Although according to him, most individuals or entities do not like to be deducted / taxed, but like it or not, they still have to govern the applicable rules.

The third informant of this research is Mrs Fitri. Almost the same as the two previous informants, this housewife has an English language education service business. She said that:

"The tax is the government levy that is withdrawn from the community, so it is not sincere, it must be paid ... If based on our rules as citizens and taxpayers ... we are obliged to pay ...only sometimes I question ... why do we have to pay the advertisement tax we don't take the road only in our place ... this tax if we say we have to pay and according to the rules, we have to, because if we don't pay, it's hard to take care of the permit. So just pay".

In general the three informants have the same opinion regarding their obligations as taxpayers, paying and reporting tax owed on the activities or income they get, even though they feel they are not sincere because they have tried hard, when they are workers, when they are Government entrepreneurs then ask them to provide mandatory contributions to the state. They also comply with taxes only when their tax obligations are detected. If it is not or has not been detected then they assume it does not need to be reported. So compliance is limited to what is detected, they pay and report because they are forced to because if they do not pay and report they are worried that their business activities will not run well due to non-compliance with taxes. 
In addition to the three previous informants. Other opinions also come from researchers informants named Mr. Zulfikar. This informant has an accounting education background, and has served as a Director in a large company in Makassar City. At present he is an entrepreneur and financier in several types of businesses including: Islamic property, leadership in a financial consultant, Laundry and Textyle. His understanding of religion is quite a lot, especially Islamic finance. So his view regarding tax is a bit different. Here are the results of the interview:

"Regarding tax compliance, do we have to be obedient and report everything ... Positive law says so, but in my opinion in Islamic Sharia we do not have obedience to sleaze because this is a form of tyrannical authority to its people because there is no shar'i order we must pay taxes ... I think tax is not something that must be taken by the state ... so that in my opinion there is no need to report it all ... but because of the tax rules like that and there are threats when not paying so well we are forced to follow it because the current tax is a very compelling rule ... but as long as the information is not identified, it's okay to report it".

From the information above shows that he personally did not agree with the tax because the tax is a form of coercion of the state to its people as an effort by the state to collect income for development financing. As for compliance, he believes that adherence is sufficient to what is identified or detected by the temporary state which does not need to be reported. Because what is done by the state by collecting taxes to its citizens is a form of tyrannical rulers by eating the property of its people, and this is prohibited in Islam. So there is no need for compliance with compliance in a way that is prohibited and not mandated.

If we look at the results of the interviews, all informants concluded that responsibly as citizens they would still pay taxes even though their hearts were uncertain. The reason they pay more tax is because they do not want to have problems in the future with their business if they do not pay taxes. It's just that it should be noted that their willingness to pay because of coercion rather than volunteerism. As for compliance, they say that they obey only what is identified / detected, while those whose taxes are not detected do not need to be reported and paid, because they assume the tax they paid is sufficient to increase state income and no one else is willing to report real income, even tax officials also when they have income or business they not all report and pay.

\section{Religiosity}

Measurement with the viewpoint of religiosity for Muslim taxpayers is an important thing and may be a factor influencing the behaviour of taxpayers for several reasons. [13] Religiosity is seen as the extent to which individuals are committed to their religion and faith and apply their teachings so that attitudes and behaviour reflect their commitment. [14] The manifestation of aspects of religiosity is expected to be reflected in the actions of every man who has faith, to him the inner values taxpayer from the trust and confidence they have cultivated a sense of carrying out the tasks civilians to the country, and contribute in giving usefulness to others.

[15] The results showed that religiosity had a positive and significant effect on tax compliance. [14] This finding supports research before, in which they stated that religious values are expected to play a role in stimulating compliant behaviour and preventing noncompliance with tax obligations through good religious beliefs encouraging an individual to comply. But it also needs to be paid attention to in addition to positively influencing the aspect of religiosity also negatively influencing. In several studies relating to tax compliance. Several studies linking tax compliance and Islamic religious perspectives show that Muslims do not need to pay taxes.

The religiosity view of taxes can have an impact on the behaviour of taxpayers, where people who believe that taxes are prohibited will 
have negative behaviour towards tax payments, while those who have a positive perception of taxes will be more committed to paying taxes. This research was conducted on Muslim entrepreneurs in the city of Makassar as an effort to express the perception of Muslim entrepreneurs about tax compliance related to one of them with aspects of religiosity. Muslim entrepreneurs have their own views regarding tax compliance.

In this interview the researcher asked how aspects of religiosity influenced them in their decision to comply or not comply with the tax obligations attached to the income they earned. As well as whether they when not paying/reporting actually belong to the category of sin according to their beliefs.

Mr Mahyudi

If based on the context that the tax is an individual or entity's obligation, so if you do not pay, then sin, pay half the payment, also sinful ... So, report it as it is. So if it's 10 million, that's 10 million

Mr Faizal

The government has rules if you want to try in Indonesia then there are tax rules ... and we must obey, as long as the tax is for the good. If we associate it with religion, it's not right, but if Ulil Amri says so, we have to come along. We use the argument to join the government. The hadith is also there, if your leader whips you, you come along. As long as it doesn't forbid us to worship.

Mrs Fitri

When it comes to sin, I do not know that it belongs to the category of sin, I do not know whether it is sin, because we also have to follow Ulil Amri. So if it's arbitrary it's not mandatory ... that's what I know but on the other hand we protest too if the government adds debt ... so that the government adds debt because there is no money so we only sincerely pay taxes.

In Islam, believers are encouraged to follow and obey Ulil Amri. This is written in the letter [16] An-Nisaa: 59:
"O you who believe, obey you to Allah and obey you to your apostles and ulil amri."

From the three informants, it was concluded that they fully followed what had become their obligation as taxpayers. The proposition they hold is obedient to the leader. Although according to them the government is not right to collect taxes on its citizens. However, it should be noted that their compliance is only with what is detected while those that are not detected are not yet compliant. This is certainly not in line with the definition of compliance.

Regarding whether or not reporting is included in the category of sin. Pak Mahyudi said that it was already dishonest meaning that it could be categorized as sin while the other two informants said that they did not know whether it was sinful or not but it was clear that they reported if it was their obligation when billed. A somewhat different opinion related to the aspect of religiosity is related to tax compliance given by Mr. Zulfikar. He thinks that tax does not exist in Islam and tax according to him is a crime. The following are the results of the interview with him.

"In Islamic Shari'a law ... We have no obedience to sleaze; I consider tax to be sleaze ... meaning that the form of ruling is the ruler to his people. Because there is no shar'i order ... actually there is a shari'a command when a crisis state, if you do not have money, do not have funds, you can collect taxes, but are limited to the rich, but in normal circumstances let alone the country has the potential to obtain abundant income from resources nature especially and other creativity I don't think is something that should be taken by the state, so we don't have to report everything".

From the above interview it is illustrated that he disagrees with the way the state earns income by imposing tax obligations on the people. What the government is doing is a form of sleaze by consuming people's property through tax collection, although in his opinion it can be done when the country is in an emergency but for the 
condition of Indonesia with abundant natural resources the state should not collect taxes on its people. And Islam strictly forbids consuming wealth in a vanity.

[17] "O you who believe, do not eat your neighbour's property in a false way."

Although he comprehensively disagrees with the tax collection carried out by the state, but as a citizen who lives and looks for income in Indonesia he feels he still needs to pay and report taxes.

But because it is a rule, when the rule threatens us ... threatening in the regulation even until the criminal means we are forced to participate, if in our circumstances we are forced, because at this time the tax is a very compelling rule that can even lead to coercion and punishment, as long as there is no identification it's okay not reported .

From the information submitted by $\mathrm{Mr}$ Zulfikar, it was concluded that the existence of coercive rules and criminal threats imposed made him forced to continue to have to pay and report taxes. However, the reported taxes are only those that are identified temporarily which are not identified do not need to be reported and it does not fall into the category of sin when it is not all reported because what the government is doing is vanity, and there is no need for obedience in sleaze. He also believes that whoever it is, even if he is a loyal state organizer or he is a person who works in the tax office no one will report the total income.

From the information he gave related to taxes, levies given by the government to the people of Indonesia are included in the category of dzolim because in Islam there is no tax even hadith the prohibition of collecting taxes, as the hadith narrated by [18] Ahmad 4/109, Abu Dawud Kitab Al-Imarah:

"Truly the perpetrators / tax collectors (dyadab) in hell"

In Islam, tax collection can be categorized as prohibited if the government uses tax revenue for something that is inappropriate or corrupt. In Qatar, the Fatwa Center (2012) cites a number of studies which state that if taxes are imposed fairly, it is not permissible to avoid them, whereas if unfair, disobedience is permitted and legal. [9] Al-Omari outlines the four (Mazhab) views on taxes as follows:

o Hanafi: They allow taxation on people if there is a need for it and such taxes.

o Maalikis: They support the government's right to impose taxes for special circumstances.

o Shafi'i: They recognize the tax validity of the rich if it is in the public interest.

$\circ$ Hanbali: They allow taxes and they consider it to be money spent on jihad

\section{Tax Knowledge}

One way to increase public awareness of taxes is to provide knowledge to taxpayers. High awareness by the community will encourage people to fulfil their obligations to register, pay and report their taxes properly, as a form of their responsibility as citizens. Tax-related knowledge is an important element when an individual is willing to report taxes voluntarily. [19] Research related to tax compliance, documents that the level of tax knowledge that underlies a person to make tax payments. From the results of the study found that taxpayers seem to have inadequate knowledge about the technical aspects of the income tax system. When taxpayers do not or do not understand, it can cause taxpayers to become disobedient either intentionally or unintentionally

Various studies have been conducted to prove that tax knowledge plays an important role in improving tax compliance. Knowledge of taxation has the potential to encourage taxpayers to be more prudent in completing their tax reporting. In this study, researchers also asked informants how tax-related knowledge affected them in terms of compliance or actually made them able to anticipate taxes.

All of the three male informants all had taxation knowledge from their current place of work or their previous place of work. That is what then helps them in terms of paying and reporting 
their taxes. but does knowledge make them obey or anticipate taxes and the results of the interview. Mr Faizal

If I have knowledge related to tax reporting, then I obey ... actually depends on the principle of benefits, for my business, I obey ... I give examples of cases, for example there are cases if selling land is usually a tax consequence, then we must look forward. ..we can simulate in the future what the consequences are ..

Mr Mahyudi's

It all depends on the intention, if the gray area is fine ... but if what is meant is clear, then avoiding is wrong. Understanding of accounting and taxation is quite helpful in making reports for the gray area, if for a clear tax object it is no longer possible to adjust ... As long as the object is correct, well cut ...

\section{Zulfikar informant}

As people who have income, they should be able to understand tax regulations which might be detected by the tax authorities.

The three informants said that knowledge was important to them in helping them identify what taxes were their obligations. knowledge makes them identify what are the consequences when they are not compliant with taxes, knowledge also helps them in identifying areas that are gray areas or areas that are still possible for them not taxed (but still according to the rules). Regarding whether knowledge allows them to look for loopholes to reduce their taxes even though they have become an object of tax, all of them agree that this is not true especially if it has been detected by the tax authorities, unless it is included in the gray area category.

While Mrs Fitri, the only female research informant in this study said that:

"My knowledge about taxes I see the consequences if the consequences are dangerous well I obey, I return to the principle of benefits".

Informants in this study use knowledge to see the principle of benefit for the business they are running. When his business has a tax obligation, he will find out the principle of benefits and consequences that accompany it to avoid violations that may arise due to ignorance. So knowledge is used solely to fulfil obligations not in order to avoid the things that have become its obligations.

Informants in this study have enough initiative to find information related to their tax obligations. Reporting and payment is done alone without using a tax consultant. With the existence of online services and the ease of obtaining information on the internet makes it easy for them to fulfil their tax obligations. Educational background and work experience are also factors that facilitate informants in fulfilling tax obligations.

\section{Justice}

[20] Taxpayers can behave obediently and voluntarily report their income to the authorities as long as they treat everything fairly. or do not comply because of the perception of justice that affects them. In other words, taxpayers with the same income, wealth and liability must be taxed at the same rate. The principle of justice emphasizes that individuals must be taxed according to their abilities.

From all informants interviewed, they had various opinions regarding tax compliance, which was associated with the aspect of fairness. Researchers on this occasion ask that how the taxes they pay do what they do is comparable with what they get.

Mr Faisal as the First Informant Argues that:

I feel that there is no sense of justice ... I take care of myself, I am a businessman, I am trying to get money ... what is the reciprocity of my country ... The government's interest towards us has income, we ourselves take care of our permits, if service good no problem ... but if we come we take care of ourselves ... it's not fair I guess ...

If related to advertisement tax from regions is not fair ... there should be a difference in tariffs between those on the edge and those in 
the City, why are the tariffs equalized ... it's not fair

Mr Mahyudi

"It seems not yet ... suppose I paid according to what I should have paid but what I received wasn't appropriate is still far from expected. Maybe it's back to the bureaucratic system that needs to be fixed but lately the system has been improved like the online system ... but it's still far from expected ... if for procedural fairness it is fair enough ... The concept of injustice is there as long as others pay. Picks according to the rules, but look at economic conditions must also be looked at because of poor entrepreneurs if cut".

"For regional taxes ... a system built by the regional revenue agency, for a system that makes people create loopholes ... If you want to be fair, the Regional Government must really be professional, just collect according to the rules but see the conditions, if the market conditions allow it must be collected and economic conditions are good people are not a problem but if it's not good it's hard to make people".

Mrs. Fitri

"If the turnover is not fair, if it is directly charged the restaurant is charged to the consumer. Because it hasn't been reduced yet, even if there is debt, it's actually not fair".

From interviews related to tax compliance juxtaposed with aspects of justice. In general, informants felt that they were reciprocated directly from the state or region for what they got had not been felt and had not been hit. They assume that injustice occurs in setting tariffs that are sometimes not appropriate because they do not see the conditions of taxpayers. They feel alone taking care of their business, trying to find income and when they get income they are taxed who only see turnover and do not see their business profitable or not. Not to mention when they found out that there were taxpayers who knew that their turnover was greater than theirs while taxes paid were below the amount they paid and reported to the state.
This aspect of justice certainly needs attention from the directorate general of taxes. Because when entrepreneurs feel that injustice has occurred, they prefer not to report their tax obligations and even if they report and pay what they submit, what they detect is done with negligence or compulsion. This is certainly not true if the state requests contributions from its citizens not accompanied by sincerity but compulsion.

\section{Conclusion}

Indonesia is a country with the largest Muslim population in the world. This country has considerable natural and human resource potential that if properly and properly managed the country and its people will prosper. State funding through taxes should be reviewed. The potential of the state to get income through tax collection is indeed great, but when it imposes a burden on the people, decreases the enthusiasm of entrepreneurs and is prohibited by religion when conditions are not emergency, then tax collection to citizens both as individuals or business entities needs to be reviewed.

Based on information obtained from the four informants interviewed by the researchers, they gave their views regarding tax compliance imposed on income for the businesses they run. the results of the overall interview with the informants concluded that responsibly as citizens they would pay taxes despite lack of sincerity. Tax compliance is more due to coercion and threats when they are not compliant. It's just that it should be noted that their willingness to pay is not volunteerism and sincerity. Compliance is only what is identified / detected while the undetected tax does not need to be reported and paid for, because they are considered sufficient to increase state income and no one else wants to voluntarily report the actual income.

The religiosity view of taxes has an impact on the behaviour of taxpayers, where people who believe that tax is prohibited by Islam will have a negative attitude towards tax payments, while those who have a positive perception of taxes will 
be more committed to tax payments. In this study, the informants were more obedient because they followed the proposition to follow the leader and contribute to the country. But honestly they also assume that the tax imposed on them is a form of tyranny and lack of creativity in the state management. Compliance with taxes that they do is limited to what is detected while the undetected does not need to be reported in full.

Tax knowledge plays an important role in increasing tax compliance. Knowledge of taxation encourages taxpayers to complete their tax reporting. All informants said that knowledge was important to them in helping them identify what taxes they were owed. Knowledge makes them identify what are the consequences when they are not compliant with taxes, knowledge also helps them in identifying areas that are gray areas or areas that are still possible for them not taxed. While things that have become their tax obligations and have been identified they will not violate.

Justice is one aspect that can influence taxpayers in reporting and paying their taxes. In general, informants felt that justice for what they paid for and direct feedback had not been felt and had not yet been hit. They assume that injustice occurs in setting tariffs that are sometimes not appropriate because they do not see the conditions of taxpayers. This aspect of justice certainly needs attention from the directorate general of taxes. Because when they feel that injustice has occurred, they prefer to disobey and even if they report and pay what they submit, what is detected is done with insincerity or compulsion.

The limitations in this study are as follows. First, research is carried out using a phenomenological approach; further research can use other approaches. Secondly, the interpretation of tax compliance of Muslim entrepreneurs in Makassar in this study cannot be generalized as a Muslim entrepreneur as a whole. Third, further research can make Muslim and non-Muslim entrepreneurs research informants, so that their views regarding tax compliance can be known.
Reference

[1] Keuangan RK, Indonesia: Nota Keuangan (beserta rancangan anggaran pendapatan dan belanja negara). Nota Keuang. Negara, p. 60. (2018)

[2] Laksono JP, Ardiyanto MD: Analisis faktor-faktor yang mempengaruhi kepatuhan wajib pajak badan pada perusahaan industri manufaktur di semarang, J. Ekon. dan Bisnis. Vol. XIII, no. 2, pp. 1-29. (2011)

[3] Syakura MA, and ZB. Determinan Perencanaan Pajak dan Perilaku Kepatuhan Wajib Pajak Badan," J. Akunt. Multiparadigma. vol. 5, no. 2. (2014)

[4] Hindriks J, Peralta S. Weber S, "Competing in taxes and investment under fiscal equalization," J. Public Econ. vol. 92, no. 12, pp. 2392-2402. (2008)

[5] Fauzia M.: Sri Mulyani Akui Penerimaan Pajak UMKM Masih Rendah Artikel ini telah tayang di Kompas.com dengan judul 'Sri Mulyani Akui Penerimaan Pajak UMKM Masih Rendah', https://ekonomi.kompas.com/read/2018/07 /14/164924926/sri-mulyani-akui-

penerimaan-pajak-umkm-masi. Kompas, (2018)

[6] Loo EC,: The influence of the introduction on selfassessment on compliance behavior of individual taxpayers in Malaysia. University of Sydney, Sydney, Australia. (2006)

[7] Wenzel M, "Tax compliance and the psychology of justice: Mapping the field," Tax. Democr. Underst. Tax Avoid. Evas, 41-70. (2017)

[8] Musimenta MSND, Naigaga S, Bananuka J, "Tax compliance of financial services firms: a developing economy perspective," J. Money Laund. Control. vol. 5, no. 3, pp. 192-243, (2002)

[9] Hassen L, Al-Ttaffi A, Abdul-Jabbar, "Does Muslim view on tax influence compliance behaviour?," Int. Conf. Account. Stud. (2015) 
[10] Salehi M, Mirzaee MA, and Yazdani M, "Spiritual and emotional intelligences, financial performance, tax avoidance and corporate disclosure quality in Iran," International Journal of Law and Management. (2017)

[11] Sheffield U, "The Qualitative Paradigm," DCU SCHOOL OF COMPUTING, [Online]. Available: https://www.computing.dcu.ie/ hruskin/R M2.htm. (2014)

[12] Edmonds WA and Kennedy TD. An Applied Guide to Research Designs: Quantitative, Qualitative, and Mixed Methods. (2020)

[13] Alm J, Tax Compliance and Administration," Handb. Tax., no. January, pp. 741-768, (2019)

[14] Pope R. M. J. The influence of religiosity on taxpayers' compliance attitudes: Empirical evidence from a mixed-methods study in Malaysia, Account. Res. J., vol. Vol. 27, no. Unit 07, pp. 1 - 91, (2010)

[15] Hanifah H Yudianto J, The Influence of Religiosity, Nationalism, and Tax Corruption Perception on Tax Compliance: Study of The Micro, Small and Medium Enterprises (MSMEs) Taxpayers in Bandung City, J. Account. Audit. Bus., vol. 2, no. 1, p. 17, (2019)

[16] Kemenag Q, An-Nisaa:59, Kemenag c.q. Lajnah Pentashihan Mushaf Al-Quran Badan Litbang dan Diklat, [Online]. Available:

https://quran.kemenag.go.id/index.php/sur $\mathrm{a} / 4$ (2016)

[17] Kemenag Q, An-Nisaa:29, Kemenag c.q. Lajnah Pentashihan Mushaf Al-Quran Badan Litbang dan Diklat, [Online]. Available:

https://quran.kemenag.go.id/index.php/pag esura/4 (2016)

[18] Ali AIM, PAJAK DALAM ISLAM, AlManhaj, (2006)

[19] Saad N, Tax Knowledge, Tax Complexity and Tax Compliance: Taxpayers' View,"
Procedia - Soc. Behav. Sci. vol. 109, no. 1, pp. 1069-1075, (2014)

[20] Dijke M, Verboon P. Trust in authorities as a boundary condition to procedural fairness effects on tax compliance. J. Econ. Psychol. vol. 31, no. 1, pp. 80-91, (2010) 